\title{
Synthesis of New Nucleoside Analogues from Theobromine
}

\author{
Thanaa M. Al-Mouamin* and Sumaya J. Abid** \\ *Corresponding Author: thanaa_ma2007@yahoo.com \\ *** Corresponding Author: sumayajamal1990@gmail.com
}

\begin{abstract}
Nucleoside Analogues play important role in different medical drugs, therefor we synthesized new nucleoside analogues using theobromine as a nucleobase, for the first time, by convertion to its mercury salt, [1]. Then coupled with three kinds of sugar, including (glucose, galactose and mannose), after protection [2-4] and activation as bromo sugar [5-7] afforded blocked nucleoside analogues [8-10] which subsequently hydrolyzed to give our synthetic goal the free nucleoside analogues [11-13]. All prepared compounds were identify by FT-IR and some of them with ${ }^{1} \mathrm{H}-$ NMR spectroscopy. The synthesized compounds (11-13) were screened for their in-vitro antibacterial and antifungal activity. [DOI: 10.22401/ANJS.00.2.03]
\end{abstract}

Keywords: Nucleoside Analogues, theobromine, mercury salt

\section{Introduction}

Nucleosides are the key to life as they make up DNA and RNA in Nature. In medicine, many drugs contain synthetic nucleosides or nucleoside analogues for the treatment of disease,especially cancer and viral infection ${ }^{[1,2]}$. Also to improve the pharmacologic activity ${ }^{[3,4]}$. A variety of functionalities have been introduced into either the sugar moiety ${ }^{[3,5]}$ or the heterocyclic moiety ${ }^{[6,7]}$. Nucleoside analogs represent a potentially important class of antiviral and anticancer agents ${ }^{[8-10]}$ with antimicrobial and cholinesterase inhibitory activities ${ }^{[11-14]}$ and are commonly used to treat hepatitis B virus ${ }^{[15,16]}$, hepatitis $\mathrm{C}$ virus ${ }^{[17]}$, herpes simplex ${ }^{[18]}$, Human Immunodeficiency Virus (HIV) and neoplasms ${ }^{[19,20]}$.

Well-established strategies of preparing $\mathrm{N}$-nucleosides include the following: (1) Fischer and Helferich reported that purine nucleosides could be synthesized by coupling purines with acetobromoglucose and applying silver or mercury salts as catalysts ${ }^{[21,22]} ;$ (2) the improved silyl-Hilbert-Johnson reaction $^{[23,24]}$, the most widely used synthetic method, involves the coupling of per-silylated heterocyclic bases with per-acylated sugars in the presence of Friedel-Crafts catalysts (e.g., $\mathrm{SnCl}_{4}$ or TMSOTf). This reaction has been the dominant method for the preparation of pyrimidine, purine and other heterocyclic nucleosides.
Theobromine (THB) is one of the major xanthine-like alkaloids, found in cacao plant and a variety of other foodstuffs such as tea leaves, guarana and cola nuts ${ }^{[25]}$.

Theobromine (from Theobroma cacoa; theo $=$ god, and broma $=$ food; thus, food of the gods) are the two most abundant methylxanthines in chocolate, both of which have received considerable attention in the food and nutrition fields, in part because of the physiological effects which they elicit $^{[26,27]}$.

Theobromine can be produced by both synthetically and natural route. For the chemical synthesis of theobromine, it is important to develop a highly steroselective process, due to the 3,7-dihydro-3,7-dimethyl1H-purine-2,6-dione are highly sterospecific nature $^{[28] \text {. }}$

\section{Experimental Part}

\subsection{Instruments and Chemicals:}

\subsubsection{Instruments:}

- Melting points were recorded by using hot stage Gallen Kamp melting point apparatus and were uncorrected, England.

- Infrared spectra were recorded using Fourier Transform infrared SHIMADZU (8300) (FTIR) infrared spectrometer, Japan, $\mathrm{KBr}$ disc in the (4000-600) $\mathrm{cm}^{-1}$ spectral range was performed by Baghdad University.

- ${ }^{1}$ H-NMR spectra was recorded on near magnetic resonance Bruker, Ulter-shield 
(400) $\mathrm{MHz}$ in Isfahan University, Iran, $\mathrm{CDCl}_{3}$ was used as solvent.

- The biological activity were screened in central environmental laboratory in collage of science in university of Baghdad.

\subsubsection{Chemicals:}

All chemicals used in this study were of the highest purity available which were supplied from BDH, Fluka and SigmaAlderich chemicals.

\subsection{Preparation of Sugar Moiety}

\subsubsection{Preparation of Beta-glucose penta acetate $[2]^{[29]}$}

A mixture of glucose $(5 \mathrm{~g}, 27.75 \mathrm{mmol})$, sodium acetate anhydrous (4 g, $48.76 \mathrm{mmol})$ and acetic anhydride $(25 \mathrm{ml})$ place in $100 \mathrm{ml}$ round bottomed flask fitted with condenser. the mixture was heated on a water bath until a clear solution is obtained (approximately 30 minutes), the mixture was shake from time to time. then heating continue for $4 \mathrm{hrs}$. the reaction mixture is pour into $(50 \mathrm{ml})$ of ice water in a beaker. the crystal was filtered at the pump and wash well with water. the product [2] is recrystallize from ethanol.(m.p 131-132), (9.3 g, 85.92\%).

\subsubsection{Preparation of 1,2:3,4-Di-O- isopropylidene- $\alpha$ - D-galacto- pyranose [3] $]^{[30 a]}$}

Freshly fused, and powdered anhydrous zinc chloride (9.5 g, $70 \mathrm{mmol}$ ) was rapidly weighed into a dry $(250 \mathrm{ml})$ Erlenmeyer flask, and $(100 \mathrm{ml})$ of dry acetone was added with stirring at room temperature until zinc chloride was dissolved. Concentrated sulfuric acid $(0.32 \mathrm{ml})$ was rapidly added drop-wise. To the resulting colorless solution finely powdered anhydrous D-galactose (9 g, 50 mmole) was added. The mixture was stirred magnetically for 4 hours. After that a suspension of (16 g) of anhydrous sodium carbonate in $(28 \mathrm{ml})$ of water was added in portions and the mixture was stirred for about one hour. The suspension was filtered, and the precipitate was washed several times with acetone. The filtrate and washings are combined, then the solution was evaporated under reduced pressure. The mixture was extracted 3 times with ether $(3 \times 10 \mathrm{ml})$, dried with anhydrous sodium sulfate, filtered, and evaporated to dryness under reduced pressure to give product [3] as pale yellow syrup, (9.54 g, 73.37\%). Compound [3] showed physical properties according reference above.

\subsubsection{Preparation of 2,3:5,6 di-O- isopropylidene- $\alpha-D$-manno furanose $[4]^{[30 b]}$}

$\alpha$-D-Mannose (5 g, 27 mole) was shaken together with a (15) fold amount of anhydrous acetone $(75 \mathrm{ml})$, containing $(3.5 \mathrm{ml})$ of conc. sulfuric acid.After (3-4 h) all the D-mannose was dissolved. The light yellow solution was neutralized with anhydrous sodium carbonate ( $8 \mathrm{~g}$ in $14 \mathrm{ml}$ water) and filtered. Then the filtrate was evaporated under reduced pressure and dissolved in a little amount of dry ether and precipitated with petroleum ether yielding [4] as yellow ppt. (6.3 g, $87.26 \%$ ).

\subsubsection{Preparation of $\alpha$-Bromo glucose tetra acetate $[5]^{[30 c]}$}

The acetylated glucose [2] (0.5 g, 1.3 mmole) was treated with $50 \%$ hydrogen bromide in glacial acetic acid $(2 \mathrm{ml})$ (which was added drop wise at $0{ }^{\circ} \mathrm{C}$. The solution was kept at $0{ }^{\circ} \mathrm{C}$ until TLC indicated reaction completion (generally within one hour) then poured into an ice-cold chloroform $(17 \mathrm{ml})$, washed with iced water $(3 \times 15 \mathrm{ml})$ and then with saturated aqueous solution of sodium bicarbonate to remove the remaining acid. After a final washed with iced water $(20 \mathrm{ml})$ the organic layer was dried over anhydrous sodium sulfate and the solvent was evaporated to give colorless syrup $(0.44 \mathrm{~g}$, $84.62 \%)$. The product was used directly for the nucleoside synthesis.

\subsubsection{Preparation of 1,2:3,4-Di-O- isopropylidene- $\alpha-D$-galactopyranosyl bromide [6] $]^{[30 b]}$}

Hydrogen bromide in glacial acetic acid $(5 \mathrm{ml})$ of $(45 \%)$ was added to $1,2: 3,4-d i-O$ isopropylidene- $\alpha$ - $D$-galactopyranose [3] (4 g) then $(5 \mathrm{ml})$ of glacial acetic acid was added. the mixture was stirred for $30 \mathrm{~min}$. at room temperature and then left for 6 hours at room temperature. The mixture left over night at $\left(5{ }^{\circ} \mathrm{C}\right)$ then the mixture was dissolve in 
chloroform and neutralized with saturated aqueous sodium bicarbonate solution and extracted with chloroform $(4 \times 8 \mathrm{ml})$, dried over anhydrous sodium sulfate, filtered and evaporated in reduced pressure to give a brown syrup (3.54 g, 71.23\%).

\subsubsection{Preparation of Bromo 2,3:5,6 di-O- isopropylidene- $\alpha-D$-manno furanose $[7]^{[30 b]}$}

Compound [4] was brominated according to the same procedure for compound [3] with some modification.Hydrogen bromide in glacial acetic acid (45\%) (2 ml) was added to 2,3:5,6-di- $O$-isopropylidene- $\alpha-D$-manno furanose [4] $(1.5 \mathrm{~g})$ then $(2 \mathrm{ml})$ of glacial acetic acid was added. the mixture was stirred for $30 \mathrm{~min}$. at room temperature and then left for 6 hours at room temperature. The mixture left over night at $(5 \mathrm{oC})$ then the mixture was dissolve in chloroform and neutralized with saturated aqueous sodium bicarbonate solution and extracted with chloroform $(3 \times 5$ $\mathrm{ml}$ ), dried over anhydrous sodium sulfate, filtered and evaporated in reduced pressure to give a brown syrup $(0.95 \mathrm{~g}, 51.08 \%)$.

\subsection{Bis (theobromine-1-yl) mercury (II)} $[1]^{[31]}$

This compound were prepared according literature $^{(31)}$ with some modification. Theobromine (1 g, $5.49 \mathrm{mmol})$ was dissolved in hot water $(30 \mathrm{~mL})$ and sodium hydroxide $(0.4 \mathrm{~g}, 5.2 \mathrm{mmol})$ was added, to vigorously stirred solution of mercuric chloride $(0.82 \mathrm{~g}$, $2.6 \mathrm{mmol})$ in hot ethanol $(50 \mathrm{~mL})$. The resulting yellow mixture was stirred at room temperature for 1.5 hours, then allowing it to stand at room temperature for 16 hours. The resulting suspension was cooled down and filtered off,then washed with distilled water until the filtrate was neutral to litmus. After filtration by suction a quantitative yield of [1] was obtained. m.p 326 dec.oC and stored in desiccators.

\subsection{General procedure for synthesis of protected nucleoside analogues $[8-10]^{[32]}$}

The theobromine mercury salt $(0.18 \mathrm{~g}$, $0.5 \mathrm{mmol}$ ) was finely powdered suspended in $(20 \mathrm{ml})$ sodium-dried $m$-xylene in the presence of celite $(1 \mathrm{~g})$ to remove trace of water the solvent was partially distilled. When the temperature of the mixture was raised to $137{ }^{\circ} \mathrm{C}$, the residual suspension was allowed to cool (below $50{ }^{\circ} \mathrm{C}$ ). The protected sugar [46] $(0.97 \mathrm{mmol})$ in dried $\mathrm{m}$ - xylene $(30 \mathrm{ml})$ was then added and refluxed with vigorous stirring for $1 \mathrm{~h}$. TLC (chloroform-ether 9:1). Indicated the presence of unreacted trace of compound which was filtered from the hot xylene suspension and washed with dichloro methane $(7 \mathrm{~mL})$. The organic layer was washed with $(3 \times 5 \mathrm{~mL})$ of $20 \%$ aqueous potassium iodide to remove the remaining trace of the mercuric salt, washed with water $(3 \times 5 \mathrm{~mL})$ dried over anhydrous sodium sulphate and the solvent was removed to give protected nucleoside analogues [8-10]. Physical properties of these compounds were listed in table (4).

\subsection{Hydrolysis of 1-(2'3':4',6'-tetra-O-Acetyl- $\beta$-D-glucopyranosyl) theobromine. $[11]^{[33]}$}

A solution of $(0.44 \mathrm{~g}, 0.862 \mathrm{mmol})$ of the blocked nucleoside [8] in $(20 \mathrm{~mL})$ of $0.1 \mathrm{M}$ methanolic sodium methoxide was refluxed with stirring for 0.5 hour TLC (DCM: EtOH 8:2)showed that the reaction was complete, the mixture was neutralized with acetic acid (5 drops) and evaporated to dryness, the residue was partitioned between water and chloroform and the aqueous phase was evaporated to dryness in vacume. To give the nucleoside analogues [11] as off white syrup. $(0.23 \mathrm{~g}, 82.14 \%)$.

\subsection{Hydrolysis of6- $\left(1^{\prime}, 2^{\prime}: 3^{\prime}, 4^{\prime}-\right.$ di-O- Isopropylidene-6 -galacto pyranosyl) theobromine. [12] $]^{[34]}$}

For galacto nucleoside [9], a solution of blocked nucleoside $(0.71 \mathrm{mmol})$ in $(47 \mathrm{ml})$ of $50 \%$ aqueous acetic acid was refluxed for 15 min. $(10 \mathrm{ml})$ of water was added and extracted with chloroform $(3 \times 5 \mathrm{ml})$, then dried over anhydrous $\mathrm{Na}_{2} \mathrm{SO}_{4}$, the solvent was evaporated to give the free nucleoside [12] $(0.19 \mathrm{~g}, 82.6 \%)$ as a yellow syrup. 
Isopropylidene- $\beta$-D-manno furanosyl)

theobromine. $[13]^{[34]}$

For manno nucleoside (10), a solution of blocked manno nucleoside $(0.8 \mathrm{mmol})$ in (53 $\mathrm{ml}$ ) of $50 \%$ aqueous acetic acid was refluxed for $15 \mathrm{~min}$. $(10 \mathrm{ml})$ of water was added and extracted with chloroform $(3 \times 7 \mathrm{ml})$, then dried over anhydrous $\mathrm{Na}_{2} \mathrm{SO}_{4}$, the solvent was evaporated to give the free nucleoside [13] $(0.2 \mathrm{~g}, 77 \%)$ as deep brown syrup.

\section{Anti-microbial activity test}

The inhibition zone of growth of microorganisms was measured against Staphylococcus aureus and Streptococcus (Gram +ve) and Escherichia coil and Pseudomonas aeruginosa (Gram -ve) and Aspergillus Flavus (fungal) using Cup-plate methods. The petridishes were placed on a flat surface to ensure that the layers of the medium were of uniform thickness. Cylindrical cavities of $6 \mathrm{~mm}$ dimeter were made on the medium. $50 \mu$ l of test and standard solutions were transferred into cylindrical cavities, the plates were incubated for $24 \mathrm{~h}$. for bacteria and $72 \mathrm{~h}$. for fungal, at $37{ }^{\circ} \mathrm{C}$ and the circular inhibition zone was measured.

\section{Results and discussion}

Theobromine (THB) is a unique natural alkaloid, for there similarity to purine molecule (adenine and guanine) also it has moderate central nervous system (CNS) stimulant. On the other hand nucleoside analogues play important therapeutic agent for cancer, viral and bacterial disease.

For these importance we synthesized new nucleoside analogues, which were synthesized first of all. The designed synthetic rout was started with thebromine as a nucleobase and three kinds of sugar (glucose, galactose and mannose) as a sugar moiety (Schem 1). 


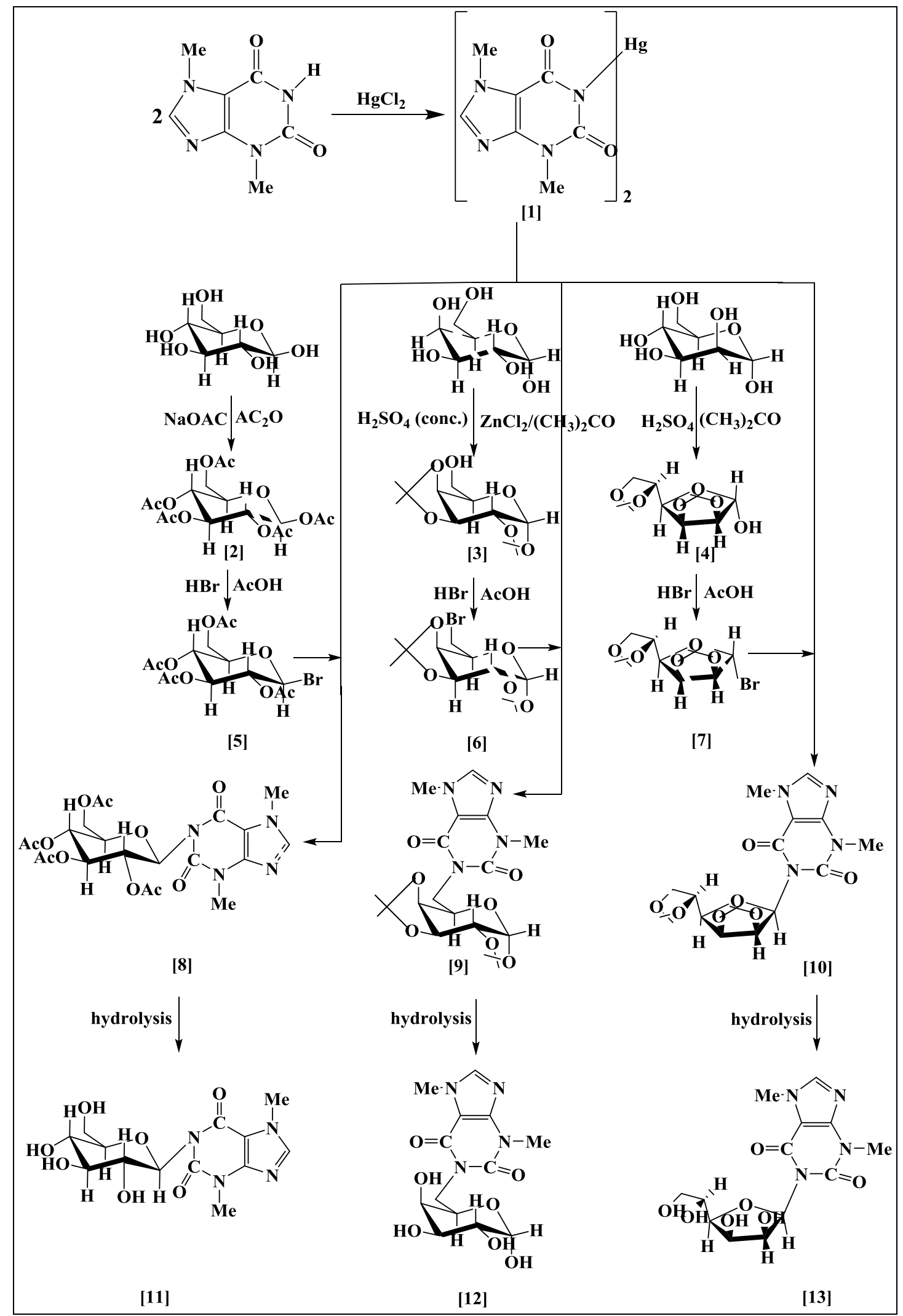

Schem 1 Synthetic rout for synthesis of nucleoside analogues.

The base theobromine was converted to its mercury salt [1] to polarized the new covalent band leading to increase the nucleophility of nitrogen atom. The (THB) salt was characterized by it's high melting point m.p > $326{ }^{\circ} \mathrm{C}$ and the FT-IR spectrum showed the disappearance of $(\mathrm{N}-\mathrm{H})$ band and other bands for theobromine itself. (table 1). 
Table 1

The FT-IR spectral data of theobromine and it's salt [1] and protected sugar.

\begin{tabular}{||c|c|c|c|c|c|c|c|c||}
\hline $\begin{array}{c}\text { Comp. } \\
\text { No. }\end{array}$ & $\boldsymbol{v}(\boldsymbol{O}-\mathrm{H})$ & $\begin{array}{c}\boldsymbol{v}(\boldsymbol{C}-\boldsymbol{H}) \\
\text { alkene }\end{array}$ & $\begin{array}{c}\boldsymbol{v}(\boldsymbol{C}=\boldsymbol{C}) \\
\text { aromatic }\end{array}$ & $\begin{array}{c}\boldsymbol{v}(\boldsymbol{C}-\boldsymbol{H}) \\
\text { aliphatic }\end{array}$ & $\boldsymbol{v}(\boldsymbol{C}=\mathrm{N})$ & $\boldsymbol{v}(\boldsymbol{C}=\mathbf{O})$ & $\begin{array}{c}\boldsymbol{v}(\boldsymbol{C}-\boldsymbol{N}) \\
\text { aromatic }\end{array}$ & Other band \\
\hline \hline $\begin{array}{c}\text { Theobro } \\
\text { mine }\end{array}$ & - & 3033 & 1548 & $\begin{array}{c}2952 \\
2885\end{array}$ & 1595 & $\begin{array}{c}1695 \\
1670\end{array}$ & $\begin{array}{c}1226 \\
1335\end{array}$ & $\begin{array}{c}3448 \text { for } \\
v(\mathrm{~N}-\mathrm{H})\end{array}$ \\
\hline 1 & - & 3118 & 1500 & 2945 & 1539 & $\begin{array}{c}1654 \\
1631\end{array}$ & $\begin{array}{c}1224 \\
1313\end{array}$ & - \\
\hline 2 & - & - & - & 2964 & - & $\begin{array}{c}1762 \\
(\text { acetyl })\end{array}$ & - & $\begin{array}{c}1074 \text { for } \\
v(\mathrm{C}-\mathrm{O}-\mathrm{C}) \\
\text { sugar }\end{array}$ \\
\hline 3 & 3465 & - & - & 2987 & - & - & - & $\begin{array}{c}\text { Sy.1039- } \\
\text { asy.1255 for } \\
v(\mathrm{C}-\mathrm{O}-\mathrm{C}) \\
\text { sugar }\end{array}$ \\
\hline 4 & 3485 & - & - & 2941 & - & - & - & $\begin{array}{c}\text { Sy.1072- } \\
\text { asy.1251 for } \\
v(\mathrm{C}-\mathrm{O}-\mathrm{C}) \\
\text { sugar }\end{array}$ \\
\hline
\end{tabular}

The ${ }^{1} \mathrm{H}-\mathrm{NMR}$ spectrum showed three singlet signals at $\delta(3.52,4.0$ and 7.54) $\mathrm{ppm}$ assigned to $\left(\mathrm{CH}_{3}-\mathrm{N}\right)$ of pyrimidine, $\mathrm{CH}_{3}-\mathrm{N}$ of imidazole and proton of imidazole respectively the aromatic proton appeared at $7.54 \mathrm{ppm})^{(35)}$ the disappearance of $\mathrm{N}-\mathrm{H}$ proton gives good indication for salt formation.

The sugar moiety was protected by too different way: glucose was protected as per acetate [2], using acetic anhydride and sodium acetate as a catalyst giving a pyrano conformation. whill galactose and mannose protected as a di-O-isopropylidene using dry acetone and freshly fused zinc chloride as a catalyst. Galactose formed pyran conformation [3], while mannose formed furan conformation [4]. The protected sugar were confermed by there physical properties which were identical with literature ${ }^{(30)}$

The FT-IR spectrum of sugar [2] showed appearance of carbonyl band of acetate group at $\left(1751 \mathrm{~cm}^{-1}\right)$ while sugars [3 and 4] showed the stretching band of ether band (C-O-C) at (1222-1240 $\mathrm{cm}^{-1}$ ) Table(1).

Glycosyl bromides are commonly synthesized by treating per acetylated sugar [3] with $\mathrm{HBr}$ in glacial acetic acid. "The more stable $\alpha$-anomer usually obtained in high yield"(36). The anomeric acetyl was converted to good leaving group by protonation as showen in (Scheme 2) giving 1- bromo sugar [5].

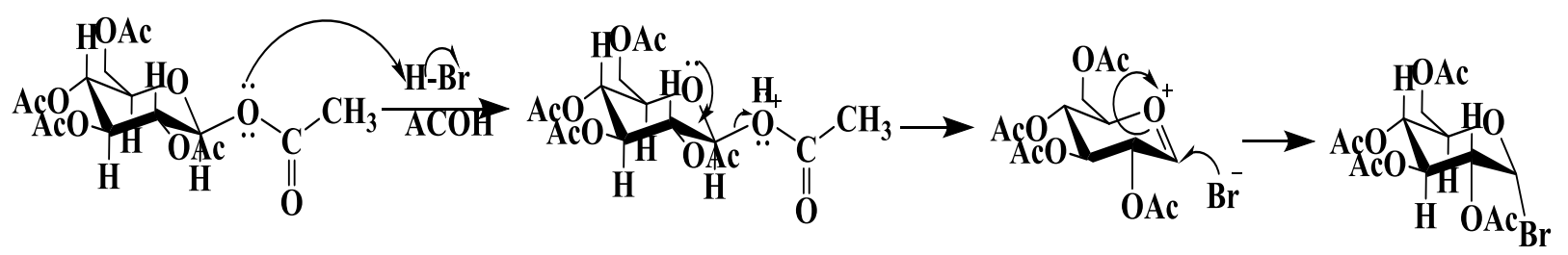

Scheme 2 Mechanism for synthesis of a-Bromo glucose tetra acetate.

Galactose and mannose were brominated at free $\mathrm{OH}$ in $\mathrm{C}_{6}$ and $\mathrm{C}_{1}$ producing bromo sugar [6] and [7] respectively. using the same reagent as in [5] with different period of reaction.Following the Koenigs- Knorr method the bromo sugar [5-7] (which was prepared immediately) was subjected to coupled with theobromine mercury salt [1] in dry xylene with appearance of celite in reflux condition afforded the protected nucleoside 
[8-10] via $\mathrm{SN}_{2}$ reaction by displacement of mercury atom by sugar bromide group. The new protected nucleoside was characterized by FT-IR spectroscopy. the spectrum showed the disappearance of $(\mathrm{C}-\mathrm{Hg})$ band and appearance of band between (1226-1375) $\mathrm{cm}^{-1}$ for $(\mathrm{C}-\mathrm{N})$ nucleoside, also showed a stretching bands of $\left(1550-1599 \mathrm{~cm}^{-1}\right)$ and at (1610-1706 $\left.\mathrm{cm}^{-1}\right)$ for $(\mathrm{C}=\mathrm{N})$ and imide carbonyl respectively for theobromine moiety.
In addition of these band nucleoside [8] showed absorption band at $1751 \mathrm{~cm}^{-1}$ for carbonyl of acetyl group in sugar moiety, while nucleoside [9 and 10] showed a stretching band at (1224-1240 $\left.\mathrm{cm}^{-1}\right)$ and at $\left(1047-1049 \mathrm{~cm}^{-1}\right)$ for asymmetric and symmetric $(\mathrm{c}-\mathrm{O}-\mathrm{c})$ for isopropylidene groups in sugar moiety. Other absorption bands are listedin (table 2).

Table 2

The FT-IR spectral data of protected nucleoside analogues [8-10]

\begin{tabular}{|c|c|c|c|c|c||}
\hline $\begin{array}{c}\text { Comp. } \\
\text { No. }\end{array}$ & $\begin{array}{c}\boldsymbol{v}(\boldsymbol{C}-\boldsymbol{H}) \\
\text { aliphatic }\end{array}$ & $\boldsymbol{v}(\boldsymbol{C}=\boldsymbol{O})$ & $\boldsymbol{v}(\boldsymbol{C}=\boldsymbol{N})$ & $\begin{array}{c}\boldsymbol{v}(\boldsymbol{C}-\boldsymbol{N}) \\
\text { aromatic }\end{array}$ & Other band \\
\hline \hline 8 & 2958 & $\begin{array}{l}1610 \\
1680 \\
1751\end{array}$ & 1595 & $\begin{array}{c}1226 \\
1369\end{array}$ & $\begin{array}{c}1041 \text { for } v(\mathrm{c}-\mathrm{O}-\mathrm{c}) \text { sugar } \\
1751 \text { for } v(\mathrm{c}=\mathrm{o}) \text { acetyl }\end{array}$ \\
\hline \multirow{2}{*}{2923} & 1606 & 1599 & $\begin{array}{c}1228 \\
1371\end{array}$ & $\begin{array}{c}v(\mathrm{c}-\mathrm{O}-\mathrm{c}) \\
\text { Sy. 1047 } \\
\text { Asy. 1224 }\end{array}$ \\
\hline & 2856 & 1706 & & $\begin{array}{c}v(\mathrm{c}-\mathrm{O}-\mathrm{c}) \\
\text { Sy. 1049 } \\
\text { Asy. 1240 }\end{array}$ \\
\hline
\end{tabular}

Nucleoside [9] conformed also by ${ }^{1} \mathrm{H}$ NMR it's spectrum showed a complecated spectrum which may be due to flipy of chair conformation that is gives other non isolated conformer which cause to interpenetrate of the signals for the same proton of two conformer as shown below:

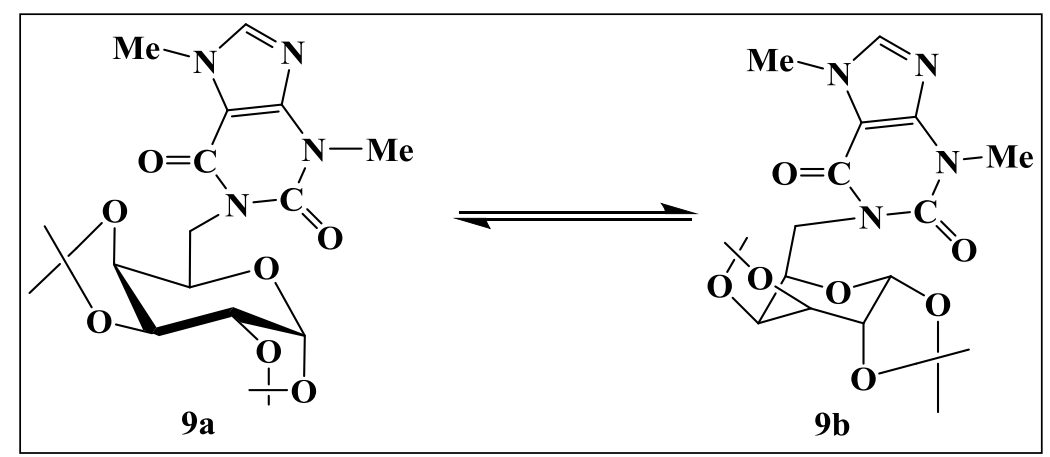

To obtain our target the free nucleoside, the protected group was hydrolyzed using sodium methoxide in methanol and aqueous acetic acid for nucleoside [8] and [9 and 10] respectively, forming new free form [11-13]. The FT-IR spectrum of these nucleoside showed the appearance of stretching band at
(3427-3390 $\mathrm{cm}^{-1}$ ) for hydroxyl group and $\mathrm{C}-\mathrm{H}$ aliphatic of sugar moiety which gives a good indication for formation of free form. Other characterastic bands for theobromine base are listed in table 3 . 
Table 3

The FT-IR spectral data for free nucleoside analogues[11-13]

\begin{tabular}{|c|c|c|c|c|c|c|}
\hline Comp.No. & $v(O-H)$ & $\begin{array}{c}v(C-H) \\
\text { aliphatic }\end{array}$ & $v(C=O)$ & $v(C=N)$ & $\begin{array}{c}v(C-N) \\
\text { aromatic }\end{array}$ & $v(c-o-c)_{\text {sugar }}$ \\
\hline 11 & 3427 & 2930 & $\begin{array}{l}1634 \\
1701\end{array}$ & 1562 & 1361 & $\begin{array}{l}1071 \\
3618\end{array}$ \\
\hline 12 & 3390 & 2963 & $\begin{array}{l}1639 \\
1704\end{array}$ & 1566 & 1340 & 1051 \\
\hline 13 & 3402 & $\begin{array}{l}2979 \\
2941\end{array}$ & $\begin{array}{l}1605 \\
1668\end{array}$ & 1580 & $\begin{array}{l}1229 \\
1373\end{array}$ & $\begin{array}{l}1080 \\
1230\end{array}$ \\
\hline
\end{tabular}

Physical properties of the prepared compounds (1) and (8-13) and other data are listed in Table 4.

Table 4

Physical properties of the prepared compounds (1) and (8-13)

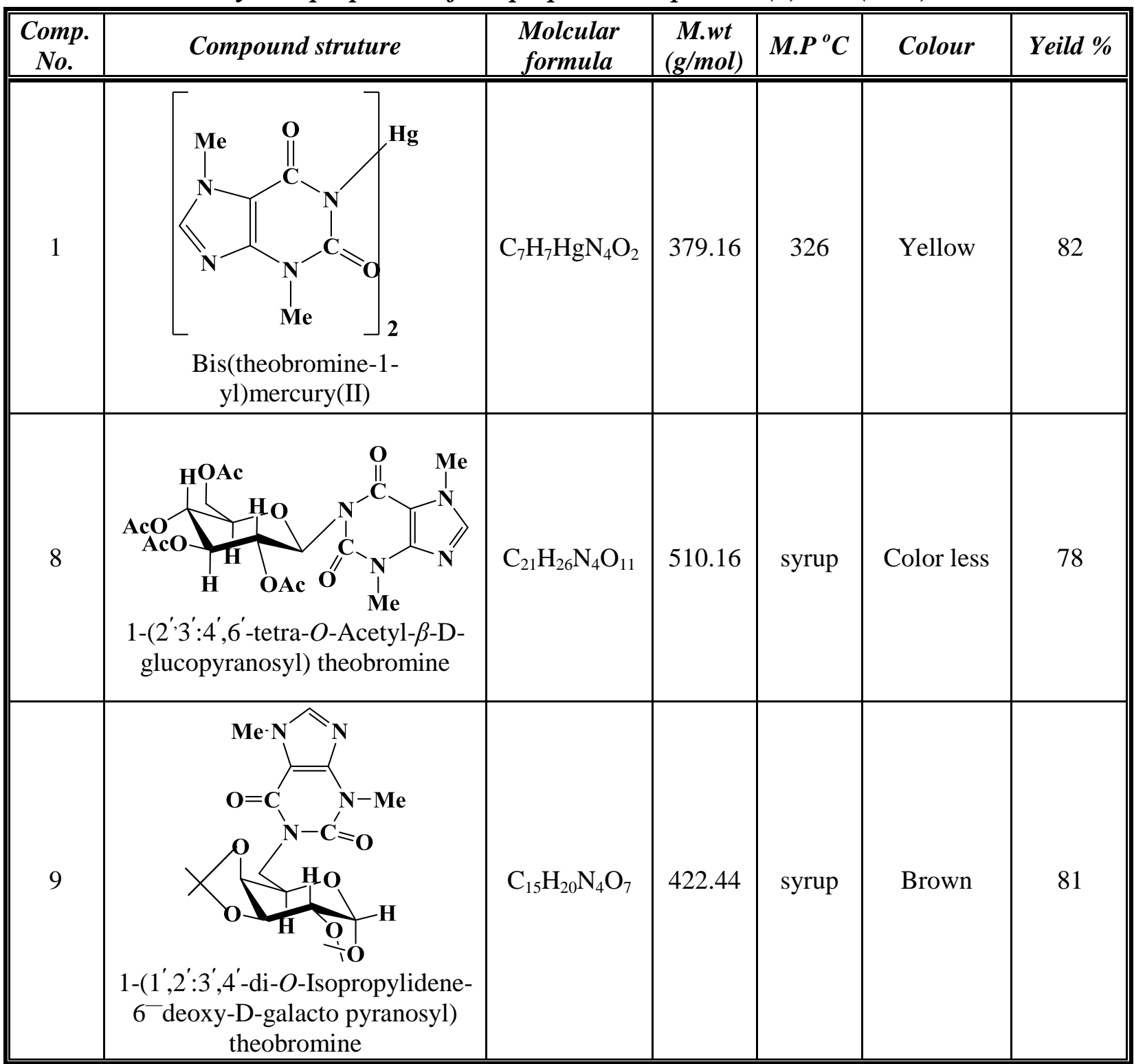




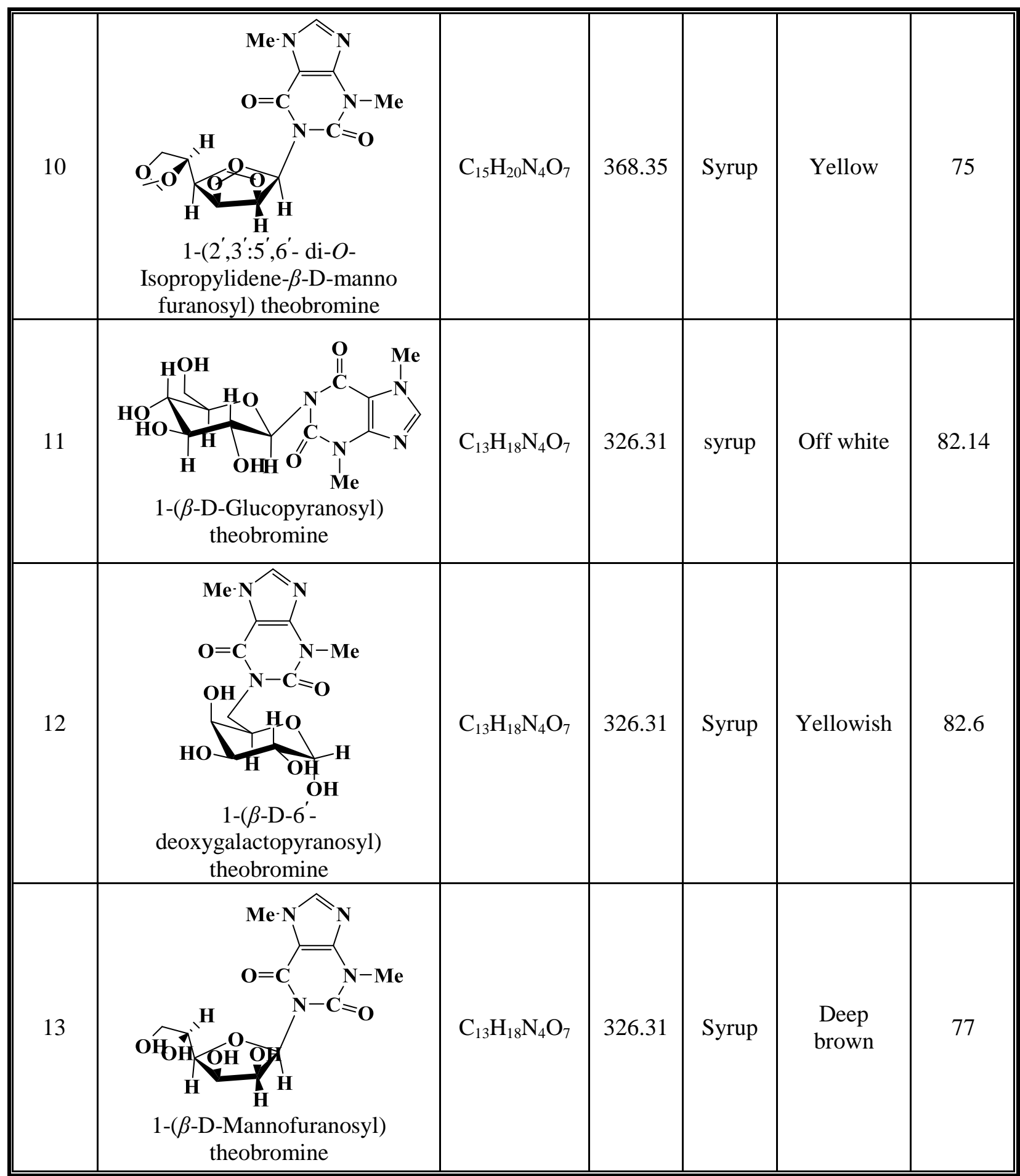

Nucleoside [11] and [13] were conformed by ${ }^{1} \mathrm{H}-\mathrm{NMR}$. The spectrum of nucleoside [11] showed two singlet signals at $\delta(1.28$ and 2.09) ppm for two $\mathrm{CH}_{3}$ group linked with nitrogen in six and five membered ring respectively. The $(\mathrm{O}-\mathrm{H})$ group appeared at $2.38 \mathrm{ppm}$ as a singlet. The sugar protons appeared at (3.4$3.9 ; 4.3-4.35 ; 4.42-4.48 ; 4.61-4.67 ; 4.87-4.91$ and 5.9-5.97) ppm as multiplet, triplet doublet, doublet and quartete assigned to $\mathrm{H}_{5}^{\prime}$, $\mathrm{H}_{4}^{\prime}, \mathrm{H}_{3}^{\prime}, \mathrm{H}_{2}^{\prime}, \mathrm{H}_{1}^{\prime}$ and $\mathrm{H}_{6}^{\prime}$ and $\mathrm{H}_{6}^{\prime \prime}$ respectively whill the $\mathrm{C}-\mathrm{H}$ aromatic protone appeared at the downfield at $7.54 \mathrm{ppm}$ as a singlet. (table 4). Nucleoside [13] showed the singlet signal at $2.03 \mathrm{ppm}$ belong to hydroxyl group the two methyl group of theobromine moiety appered as a singlet at (3.4 and 3.91) ppm other singlet appeared at downfield $7.53 \mathrm{ppm}$ for $\mathrm{C}-\mathrm{H}$ theobromine, the sugar protons appeared as multiplet, doublet, multiplet, double-doublet, doublet and doublet for $\mathrm{H}_{5}^{\prime}, \mathrm{H}_{4}^{\prime} \mathrm{H}_{6}^{\prime}, \mathrm{H}_{6}^{\prime \prime}, \mathrm{H}_{3}^{\prime}$, $\mathrm{H}_{2}^{\prime}$ and $\mathrm{H}_{1}^{\prime}$ in the region between (5.08-6.97) ppm. All these data are listed in (table 5). 
Table 5

${ }^{1} H-N M R$ - Spectral data for compound $(1,9,11,13)$

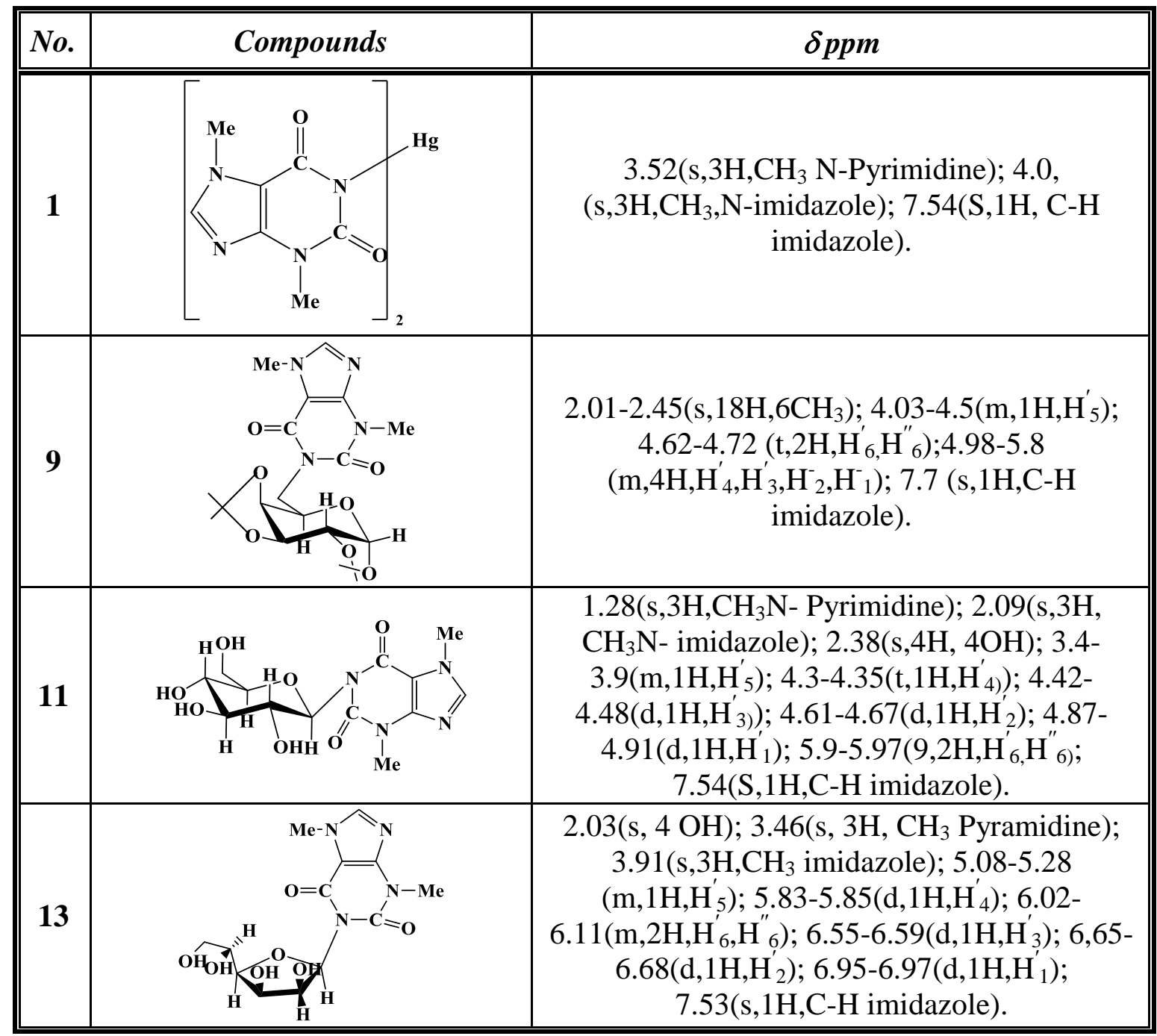

\section{Biological activity}

Microbiological Test: The synthesized compounds [11-13] were screened in vitro against four types of bacteria including, staphylococcus aurus and streptococcus as gram positive and E.coil and pseudomonas auroginosa as gram negative,also screened antifungal activity against Aspergillus Flavus. The obtained results are listed in table (5)
Showed that all synthesized compound have good activity against the four types of bacteria, while inactive against all types of fungi used for this test. This results indicate that the synthesized compounds is specific as antibacterial. This results was coincide with literature $^{[37]}$.

Table 6

Inhibition Zones of compounds (11-13)

\begin{tabular}{|c|c|c|c|c|c||}
\hline \hline Comp. No. & $\begin{array}{c}\text { Escherichia } \\
\text { coil }\end{array}$ & $\begin{array}{c}\text { Pseudomonas } \\
\text { auroginosa }\end{array}$ & $\begin{array}{c}\text { Staphylococcus } \\
\text { aurus }\end{array}$ & Streptococcus & $\begin{array}{c}\text { Aspergillus } \\
\text { Flavus }\end{array}$ \\
\hline \hline Control & - & - & - & - & - \\
\hline 11 & 9 & 10 & 12 & 10 & - \\
\hline 12 & 12 & 8 & 11 & 9 & - \\
\hline 13 & 10 & 11 & 12 & 8 & - \\
\hline
\end{tabular}




\section{References}

[1] Downey A.M., Richter C., Pohl R., Mahrwald R. and Hocek M., "Direct onepot synthesis of nucleosides from unprotected or 5-O-monoprotected dribose". Organic letters, 17(18), pp.46044607, 2015.

[2] Jordheim L.P., Durantel, D., Zoulim, F. and Dumontet, C. "Advances in the development of nucleoside and nucleotide analogues for cancer and viral diseases". Nature reviews Drug discovery, 12(6), p.447, 2013.

[3] Al-Mouamin T. and Mehdi D. "Synthesis of new nucleoside analogues via mannich base and studding their biological activities". Inorganic chemistry, 11(2), 073-085, (2016).

[4] Soul M., Suasan F., Yogesh S., Jyoti C., Muthupandian G., Namakkal G., RameshV. and Miguel F. "Design and Divergent synthesis of Azo Nucleosides from a chiral imino sugar " the Journal of Organic chemistry, 77, 4671-4678, (2012).

[5] Collins C. and Patricia M. "Chemical synthesis of nucleoside analogues" published by John wiely and sons onc. Hoboken New York Second addition, (2013).

[6] Al-Mouamin T.,Al-Lami N.,Rahman S., and Ali R. "Synthesis, Characterization and Antimicrobial activity of new nucleoside analogues from benzotriazole" chemistry \& chemistry technology, 10(3), 271-278, (2016).

[7] Mhristophe L. and Gerald E., Molecules, 20,4967, (2015).

[8] Crespan E., Garbelli A., Amoroso A. and Maga G., "Exploiting the nucleotide substrate specificity of repair DNA polymerases to develop novel anticancer agents". Molecules, 16(9), pp.7994-8019, 2011.

[9] Robak T., Korycka A., Lech-Maranda E. and Robak P., "Current status of older and new purine nucleoside analogues in the treatment of lymphoproliferative diseases". Molecules, 14(3), pp.11831226, 2009.

[10] Yu Q., Schwidom D., Exner A., Carlsen P., "Synthesis of Novel Homo-N-
Nucleoside Analogs Composed of a Homo-1,4-Dioxane Sugar Analog and Substituted 1,3,5-Triazine Base Equivalents" Molecules, 13, 3092-3106, 2008.

[11] Vitali L.A., Petrelli D., Lambertucci C., Prenna M., Volpini R. and Cristalli G., "In vitro antibacterial activity of different adenosine analogues" Journal of medical microbiology, 61(4), pp.525-528, 2012.

[12] Xavier N.M., Schwarz S., Vaz P.D., Csuk R. and Rauter A.P., "Synthesis of Purine Nucleosides from D-Glucuronic Acid Derivatives and Evaluation of Their Cholinesterase-Inhibitory Activities". European Journal of Organic Chemistry, 2014(13), pp.2770-2779, 2014.

[13] Schwarz S., Csuk R. and Rauter A.P., "Microwave-assisted synthesis of novel purine nucleosides as selective cholinesterase inhibitors". Organic \& biomolecular chemistry, 12(15), pp.24462456, 2014.

[14] Batista D., Schwarz S., Loesche A., Csuk R., Costa P.J., Oliveira M.C. and Xavier N.M., "Synthesis of glucopyranos-6'-yl purine and pyrimidine isonucleosides as potential cholinesterase inhibitors. Access to pyrimidine-linked pseudo disaccharides through Mitsunobu reaction". Pure and Applied Chemistry, 88(4), pp.363-379, 2016.

[15] Lalanne M., Andrieux K. and Couvreur P., "Strategies to increase the oral bioavailability of nucleoside analogs". Current medicinal chemistry, 16(11), pp.1391-1399, 2009.

[16] Lin T.S., Luo M.Z., Liu M.C., Pai S.B., Dutschman G.E. and Cheng Y.C., "Synthesis and biological evaluation of 2', 3'-dideoxy-L-pyrimidine nucleosides as potential antiviral agents against human immunodeficiency virus (HIV) and hepatitis B virus (HBV)". Journal of medicinal chemistry, 37(6), pp.798-803, 1994.

[17] Klumpp K., Lévêque V., Le Pogam S., Ma H., Jiang W.R., Kang H., Granycome C., Singer M., Laxton C., Hang J.Q. and Sarma K., "The novel nucleoside analog R1479 (4'-azidocytidine) is a potent inhibitor of NS5B-dependent RNA 
synthesis and hepatitis $\mathrm{C}$ virus replication in cell culture", Journal of Biological Chemistry, 281(7), pp.3793-3799, 2006.

[18] Smith K.O., Galloway K.S., Kennell W.L., Ogilvie K.K. and Radatus B.K., "A new nucleoside analog, 9-[[2-hydroxy-1(hydroxymethyl) ethoxyl] methyl] guanine, highly active in vitro against herpes simplex virus types 1 and 2 . Antimicrobial agents and chemotherapy", 22(1), pp.55-61, 1982.

[19] Vince R., Hua M., Brownell J., Daluge S., Lee F., Shannon W.M., Lavelle G.C., Qualls J., Weislow O.S., Kiser R. and Canonico P.G., "Potent and selective activity of a new carbocyclic nucleoside analog (carbovir: NSC 614846) against human immunodeficiency virus in vitro", Biochemical and biophysical research communications, 156(2), pp.1046-1053, 1988.

[20] Rabkin C.S., "AIDS and cancer in the era of highly active antiretroviral therapy (HAART)". European Journal of Cancer, 37(10), pp.1316-1319, 2001.

[21] Yamaoka N., Aso K. and Matsuda K., "New Syntheses of Nucleosides. 1a The Syntheses of Glycopyranosides of Purines, Pyrimidine, and Benzimidazole", The Journal of Organic Chemistry, 30(1), pp.149-152, 1965.

[22] Jungmann O. and Pfleiderer W., "A new efficient method in nucleoside synthesis", Tetrahedron letters, 37(46), pp.83558358, 1996.

[23] Niedballa U. and Vorbrüggen H., "Synthesis of nucleosides 17. A general synthesis of $\mathrm{N}$-glycosides. 6. On the mechanism of the stannic chloride catalyzed silyl Hilbert-Johnson reaction", The Journal of organic chemistry, 41(12), pp.2084-2086, 1976.

[24] Vorbrüggen H., Krolikiewicz K. and Bennua B., "Nucleoside syntheses, XXII1) Nucleoside synthesis with trimethylsilyl triflate and perchlorate as catalysts". Chemische Berichte, 114(4), pp.1234-1255, 1981.

[25] Clough B.H., Ylostalo J., Browder E., McNeill E.P., Bartosh T.J., Rawls H.R., Nakamoto, T. and Gregory C.A., "Theobromine upregulates osteogenesis by human mesenchymal stem cells in vitro and accelerates bone development in rats", Calcified tissue international, 100(3), pp.298-310, 2017.

[26] González D., González C., González A. \& Fuentes A. "Synthesis of caffeine from theobromine: bringing back an old experiment in a new setting" Educación Química, 26(1), 9-12, (2015).

[27] Beckers J.L., "The determination of caffeine in coffee: Sense or nonsense?". Journal of chemical education, 81(1), p.90, 2004.

[28] Kumar N.S., Chandran T.B., Namratha S., Bharat B.R., Kumar C.H.P. and Kishore V., "Production of theobromine from Pseudomonas sp", Int. Res. J. Pharm, 4, 2013.

[29] Vogel A., "Atext Book of Paractjical Organic Chemistry" Logman Group Limited. P.452, (1971).

[30] Tipson S.R.In, "Methods in carbohydrate chemistry", Vol.(II), (Wistter, R.L. and Wolfrom,M.L.,eds), p.247, A cademic press Inc. New York and London. (a) p.247, (b) p.319, (c) p.226, (1963).

[31] Freestone A.J., Hough L. and Richardson A.C., "A convenient procedure for the synthesis of theophylline nucleosides", Carbohydrate Research, 28(2), pp.378386, 1973.

[32] Al-Mouman T. " Synthesis of 2,3 dideoxy 3,3 gem-di-C- alkyl pyrono nucleouside analogues" Ph.D thesis department of chemistry college of science university of Bagdad, Iraq, (2007).

[33] Zemplén G., Gerecs A. and Hadácsy I., "Über die Verseifung acetylierter Kohlenhydrate". Berichte der deutschen chemischen Gesellschaft $(A$ and $B$ Series), 69(8), pp.1827-1829, 1936.

[34] Crews P. Rodriguez J. Jaspers M. " Organic structure analysis" $1^{\text {st }}$ Ed. New York by oxford university press p. 91, (1998).

[35] Silverstein R.M., Webster F.X., Kiemle D.J., \& Bryce D.L., "Spectrometric identification of organic compounds", John wiley \& sons, (2014).

[36] Kennedy J.F., "Carbohydrate chemistry", Clarendon Press,Oxford, p.448, 1988. 
Special Issus: $1^{\text {st }}$ Scientific International Conference, College of Science, Al-Nahrain University, 21-22/11/2017, Part II, pp.17-29

[37] Block J.H. and Beale J.M., "Wilson and Gisvold's Textbook of Organic Medicinal and Pharmaceutical Chemistry" $11^{\text {th }}$ Lippincott Williams and Wilkins, (2004). 